\title{
INFORMED CONSENT IN MEDICAL MALPRACTICE
}

In the absence of special circumstances, a physician may not treat a patient without first obtaining his consent. Courts in many jurisdictions, however, have questioned whether consent should be binding where the patient does not, at least in some measure, consciously weigh the risks of undergoing treatment against the risks of foregoing treatment. A decision to undergo treatment despite such risks is the product of "informed consent." But the average patient's ignorance of medical science very likely makes hinl unaware of particular risks inherent in a proposed treatment, and hence prevents him fron giving the informed consent which the law requires. Informed consent, therefore, concerns the extent to which a doctor nuust disclose risks inherent in a conteniplated nethod of treatment.

The following hypothetical situation illustrates problems which occasionally arise. Wendy Smith, a housewife with prior history of an overactive thyroid gland, visits her doctor for a checkup. After thorough examination, the doctor discovers that Wendy's thyroid gland again requires treatment. The three methods of treating her condition each involve certain collateral hazards. ${ }^{1}$ Collateral hazards, as unavoidable

${ }^{1}$ Surgical treatment (subtotal thyroidectomy) has successful results in $83.5 \%$ of cases. Colcock \& King, The Mortality and Morbidity of Thyroid Surgery, in SURGICAI PrAcricE OF THE LAHEx Cinnic 124 (3d ed. 1962). Surgery provides immediate relief from the severe lieart strain caused by extreme liyperthyroidism and allows rapid return to gainful employment. The major risks involved in surgery are: (1) removal of too much of the gland causing hypothyroidism; (2) damage to or removal of the parathyroid glands located on the rear of the thyroid causing parathyroid tetany which, unless controlled by hormones, can he fatal; (3) damage to the recurrent laryngeal nerves which run through the rear of the thyroid causing paralysis of one or both of the vocal cords. If one cord is paralyzed the patient's voice becomes harsh. If hoth cords are paralyzed they collapse across the trachea and suffocate the patient. F. Homans, A TextBoox or Surgery 687-91 (6th ed. 1945). Because of ahnormalities in the location of the nerves, see W. Rustad, THE Recurrent Laryingeas Nerves IN Thyrom SURGery (1956), there is an irreducible minimum incidence of damage to them in subtotal thyroidectomies. Roberts v. Wood, $206 \mathrm{~F}$. Supp. 579, 582 (SD. Ala. 1962). The lowest reported incidence of damage is 1\%. 4 R. GRAY, ATtORNEY'S TEXTBOoK OF MEDICINE If 306.28, at 3358 (3d ed. 1966). Where the operation is performed a second time hecause of recurrence of symptoms the incidence of laryngeal nerve damage is $14.7 \%$. Cattell \& Morgan, Recurrent Hyperthyroidism, in SuRGical PrACTICE OF THE LAHEX CIINIC 87 (1941).

The second method of treatment, radioiodine, is successful in $80 \%$ of the cases. $4 \mathrm{R}$. GRAX, supra, at 3358. Where the patient lias had a previous thyroidectomy, it is the hest method hecause there is no chance of injury to the nerves or to the parathyroid. Colcock, Surgery of Primary Hyperthyroidism, in SuRgicad PRACTICE of THE LaHex Clinic 86 (3d ed. 1962). Radioactive iodine treatment is best for patients who are poor surgical risks, hut it is ineffective agaiust cancer of the thyroid and is larmful if the patient is pregnant. Disadvantages of the treatunent are the difficulty in calculating the proper dosage and 
byproducts of the treatment, inevitably occur in a certain percentage of cases through no fault of the physician. ${ }^{2}$ Wendy's doctor decides to repeat the surgical treatment which he had previously given her with no ill effects. The doctor neglects to disclose either the risks attendant upon this particular method ${ }^{3}$ or the risks attendant upon alternative methods of treatment. Convinced of its necessity, Wendy consents to the operation which is perforned with reasonable skill and care. Unfortunately, however, Wendy's vocal cords are paralyzed and a tracheotomy is required. ${ }^{4}$ Unable to speak above a harsh, unfeminine whisper, Wendy will breathe through a tracheal tube for the rest of her hife.

Wendy brings a suit alleging that her doctor failed to disclose the substantial known risk of vocal cord paralysis, of which she was unaware, and that she would not have consented to the operation had she known the risk. She claims, therefore, that her doctor is liable for failure to secure informed consent. In the past decade, twenty-two jurisdictions have evolved standards for such causes of action. ${ }^{5}$ All of the standards, how-

the hypothyroidism caused by an overdose. Bartels \& Corn, Thyroidectomy for Byperthyroidism Following Unsatisfactory Response to Radioiodine Treatment, in SURGICAL PRACTICE of THE LAHEY CIINIC 113 (3d ed. 1962). Where the patient needs to return to work or has a serious heart problem, the waiting period for radioiodine to take effect may be too long. Id. at 121.

Antithyroid drugs (thiouracils) are the third method of treatment. They reduce the overactivity and strain on the heart immediately with no danger to the recurrent laryngeal nerves or to the parathyroid gland. The method is successful in only $52 \%$ of the cases, and permanent cures require up to twenty-four months of dosage, the longest period for any of the methods. $4 \mathrm{R}$. GRAY, supra, at 3358. The major disadvantage of the treatment is the high rate of remissions of hyperthyroidism after temporary relief. Id.

2 See, e.g., Roberts v. Wood, 206 F. Supp. 579, 582 (S.D. Ala. 1962) (damage to the recurrent laryngeal nerves).

$\mathbf{3}$ "Permanent bilateral nerve paralysis is the most serious of all complications of thyroid surgery ...." Colcock \& King, supra note 1, at 126. See also note 1 supra.

${ }^{4} \mathrm{~A}$ tracheotomy is "an operation consisting of making an opening through the patient's neck into the windpipe and the insertion of a 4-inch metal tube through which the patient breathes." DiFilippo v. Preston, 53 Del. 539, 542, 173 A.2d 333, 335 (1961).

5 See Roberts v. Wood, 206 F. Supp. 579 (SD. Ala. 1962); Hall v. United States, 136 F. Supp. 187 (W.D. La. 1955), aff'd, 234 F.2d 811 (5th Cir. 1956); Patrick v. Sedwick, 391 P.2d 453 (Alaska 1964), damage decision of lower court on remand vacated, 413 P.2d 169 (Alaska 1966); Shetter v. Rochelle, 2 Ariz. App. 358, 409 P.2d 74 (1965), modified, 2 Ariz. App. 607, 411 P.2d 45 (1966); Pedesky v. Bleiberg, 251 A.C.A. 119, 59 Cal. Rptr. 294 (1967); Dunlap v. Marine, 242 Cal. App. 2d 162, 51 Cal. Rptr. 158 (1966); Bradford v. Winter, 215 Cal. App. 2d 448, 30 Cal. Rptr. 243 (1963); Salgo v. Leland Stanford Jr. Univ. Bd. of Trustees, 154 Cal. App. 2d 560, 317 P.2d 170 (1957); DiFilippo v. Preston, 53 Del. 539, 173 A.2d 333 (1961); Ditlow v. Kaplan, 181 So.2d 226 (Fla. App. 1965); Grosjean v. Spencer, 140 N.W.2d 139 (Iowa 1966); Yeates v. Harms, 193 Kan. 320, 393 P.2d 982 (1964); Williams v. Menelian, 191 Kan. 6, 379 P.2d 292 (1963); Natanson v. Kline, 186 Kan. 393, 350 P.2d 1093, modified, 187 Kan. 186, 354 P.2d 670 (1960); Carroll v. Chapman, 139 So. 2d 61 (La: App. 1962); Haggerty-v. McCarthy, 344 Mass. 136, 181 N.E.2d 562 (1962); Roberts v. Young, 369 Mich.-133,-119 N.W.2d 62\%.(1963); Bang. v. Charles T. 
ever, involve practical difficulties which, in Wendy's situation, would generally preclude recovery. ${ }^{6}$

The majority standard imposes hability for failure to disclose a risk only where the patient can prove that it was the custom in the community for doctors to disclose such risks. ${ }^{7}$ The difficulty of securing expert testimony to prove such a custom ${ }^{8}$ is such that Wendy would probably not be able to recover in majority jurisdictions. ${ }^{0}$ Indeed, many courts would not impose hability even for total nondisclosure if nondisclosure were the community standard. ${ }^{10}$

Nor would Wendy be able to recover under any of the minority standards. Although some courts posit a duty of absolute ${ }^{11}$ or full ${ }^{12}$ disclosure of collateral hazards, these courts have either himited their standards to cases involving radical treatment such as shock therapy or

Miller Hosp., 251 Minn. 427, 88 N.W.2d 186 (1958); Aiken v. Clary, 396 S.W.2d 668 (Mo. 1965); Mitchell v. Robinson, 334 S.W.2d 11 (Mo. 1960); Woods v. Brumlop, 71 N.M. 221, 377 P.2d 520 (1962); Di Rosse v. Wein, 24 App. Div. 2d 512, 261 N.YS.2d 623 (1965); Watson v. Clutts, 262 N.C. 153, 136 S.E.2d 617 (1964); Mayor v. Dowsett, 240 Ore. 196, 400 P.2d 234 (1964); Gray v. Grunnagle, 423 Pa. 144, 223 A.2d 663 (1966); Block v. McVay, 80 S.D. 469, 126 N.W.2d 808 (1964); Ball v. Mallinkrodt Chem. Works, 53 Tenn. App. 218, 381 S.W.2d 563 (1964); Bell v. Umstattd, 401 S.W.2d 306 (Tex. Civ. App. 1966); Scott v. Wilson, 396 S.W.2d 532 (Tex. Civ. App. 1965), affd, 412 S.W.2d 299 (Tex. 1967); Govin v. Hunter, 374 P.2d 421 (Wyo. 1962).

B This introductory hypothetical combines the fact situations of four cases. In Roberts v. Wood, 206 F. Supp. 579 (S.D. Ala. 1962), the doctor performed a second thyroidectomy without informing the patient of the second operation's greater risk or suggesting the preferable radioiodine method of treatment, and the patient lost the use of her true vocal cords. In Patrick v. Sedwick, 391 P.2d 453 (Alaska 1964), a referring physician told plaintiff it was nothing more than a tonsillectomy. Plaintiff's consultation with the surgeon was limited to an exchange of greetings. After the operation one vocal cord was paralyzed and plaintiff's soft, feminine voice became harsh and hoarse. In DiFilippo v. Preston, 53 Del. 539, 173 A.2d 333 (1961), the doctor did not warn the patient of the risk, and now the patient cannot speak above a hoarse whisper and will breathe through a tracheal tube for the rest of her life. In Watson v. Clutts, 262 N.C. 153, 136 S.E.2d 617 (1964), the doctor told the patient she would have to stay in the hospital for a week before the serious operation. She suffered paralysis of both vocal cords and had to have a tracheotomy. Plaintiff in each of these cases lost on the informed consent theory. The plaintiff in Patrick v. Sedwick, supra, recovered on a neghigence theory.

7 The standard of the majority rule is variously stated as the "reasonable doctor," "good medical practice," or "custon of physicians in the community." Each requires expert testimony. See notes 20-32 infra and accompanying text.

${ }^{8}$ See notes $46-67$ infra and accompanying text.

9 See cases cited note 6 supra.

10 Natanson v. Kline, 187 Kan. 186, 189, 354 P.2d 670, 673 (1960) (dictum).

11 See Salgo v. Leland Stanford Jr. Univ. Bd. of Trustees, 154 Cal. App. 2d 560, 317 P.2d 170 (1957).

12 Mitchell v. Robinson, 334 S.W.2d 11 (Mo. 1960); Woods v. Brumlop, 71 N.M. 221, 377 P.2d 520 (1962). Missouri has since overruled the Mitchell full disclosure rule and now follows the majority standard. Aiken v. Clary, 396 S.W.2d 668 (Mo. 1965). All of these cases involved injury suffered during shock therapy. 
avoided applying their standards by allowing the physician a "certain discretion."13 The minority standards are at best of limited value, and at worst, confusing in application.

This Comment first examines current standards of disclosure, which do not protect Wendy and others similarly situated. The Comment therefore proposes a new standard which, if applied, would protect Wendy. It then examines the background, effects and abuses of both the current and proposed standards.

$\mathbf{I}$

RECENT JUDICIAL TREATMENT

The theory of informed consent, while not unique to this decade,${ }^{14}$ has aroused a great deal of attention since $1960 .{ }^{15}$ Neither courts nor plaintiffs are sure how to treat the theory. Suits have variously been based on theories of battery ${ }^{16}$ and negligence. ${ }^{17}$ The choice of theory of recovery will have an effect upon the requirement of expert testimony, the amount and nature of damages, the applicable period of the statute of limitations and the coverage of the defendant's insurance policy. ${ }^{18}$ Many opinions

\footnotetext{
13 Salgo v. Leland Stanford Jr. Univ. Bd. of Trustees, 154 Cal. App. 2d 560, 578, 317 P.2d 170, 181 (1957).

A physician violates his duty to his patient and subjects himself to hability if he withholds any facts which are necessary to form the basis of an intelligent consent by the patient to the proposed treatment. ... At the same time, the physician must place the welfare of his patient above all else and this very fact places him in a position in which he sometimes anust choose between two alternative courses of action. ... One is to explain to the patient every risk attendant upon any surgical procedure or operation. .. The other is to recognize that each patient presents a separate problem, that the patient's mental and emotional condition is important and in certain cases may be crucial, and that in discussing the element of risk a certain amount of discretion must be employed consistent with the full disclosure of facts necessary to an informed consent.
}

Id. This language is often quoted, although in two disparate fashions. A plaintiff's counsel will cite the first sentence for the proposition that there is a duty of absolute disclosure, or a court will cite the entire passage, without further analysis, to justify its decision for the defendant. The true meaning of the passage is veiled and uncertain to both bench and bar.

14 See, e.g., Wall v. Brim, 138 F.2d 478 (5th Cir. 1943), consent issue tried on remand, verdict for plaintiff aff'd, 145 F.2d 492 (5th Cir. 1944), cert. denied, 324 U.S. 857 (1945); Paulsen v. Gunderson, 218 Wis. 578, 260 N.W. 448 (1935).

15 The two leading cases causing the burst of renewed interest were Natanson v. Kline, 186 Kan. 393, 350 P.2d 1093, modified, 187 Kan. 186, 354 P.2d 670 (1960), and Mitchell v. Robinson, 334 S.W.2d 11 (Mo. 1960), handed down within two days of each other in April 1960. The third major case in the area, DiFilippo v. Preston, 53 Del. 539, 173 A.2d 333, was decided in June 1961.

16 E.g., Scott v. Wilson, 396 S.W.2d 532, 535 (Tex. Civ. App. 1965), aff'd, 412 S.W.2d 299 (Tex. 1967).

17 E.g., Aiken v. Clary, 396 S.W.2d 668 (Mo. 1965).

18 An informed consent complaint framed in terms of negligence alleges that the 
manifest judicial confusion as to which standard to adopt, though few opinions parallel the confusion of a court which in the same case offered four different standards of disclosure. ${ }^{10}$ Most courts, perhaps reluctant to

physician's failure to disclose was a breach of the duty of due care. The existence and extent of a physician's duty must he established by expert testimony. Authorities cited note 23 infra. A battery complaint in informed consent alleges that the physician's failure to disclose vitiated the consent and hence termimated the doctor's privilege to touch the patient's body. No expert testimony is needed, since termination of the privilege makes the professional standard of due care irrelevant. See Mitchell v. Robinson, 334 S.W.2d 11 (Mo. 1960); Woods v. Brumlop, 71 N.M. 221, 277 P.2d 520 (1962); Scott v. Wilson, 396 S.W.2d 532 (Tex. Civ. App. 1965). In some states battery and negligence causes of action can be joined in the same complaint. See Estrada v. Orwitz, 75 Cal. App. 2d 54, 57, 170 P.2d 43, 45 (1946).

While the hattery theory should be retained for those cases in which the doctor operated on the wrong part of the body, Mohr v. Williains, 95 Minn. 261, 104 N.W. 12 (1905), or acted viciously out of anger, Keen v. Coleman, 67 Ga. App. 331, 20 S.E.2d 175 (1942), treating the informed consent action as sounding in neghigence, as most courts have done, Note, 75 HARv. L. REv. 1445, 1446 (1962), will promote harmony with the rest of tort law. In the majority of cases the physician's default lies in failing adequately to educate his patient as to the collateral risks involved in the treatment. In the main he has a beneficent motive and therefore lacks the malicious or antisocial state of mind traditionally associated with battery actions. McCoid, A Réappraisal of Liability for Unauthorized Medical Trealment, 41 MnNv. L. REv. 381, 424 (1957). Because the doctor's acts in treating his patient constitute a battery if the nondisclosure vitiates the patient's consent, the physician may be held liable for acts to which the patient in fact has consented. Shetter v. Rochelle, 2 Ariz. App. 358, 409 P.2d 74, 83 (1965), modified, 2 Ariz. App. 607, 411 P.2d 45 (1966). If, however, the doctor is held hable for negligent nondisclosure, recovery may be confined to only those risks to which plaintiff did not consent. Id.

If the battery theory is used, the physician would lave to compensate the plaintiff for all harm resulting from an operation and might even be liable for pumitive damages, Oppenheim, Informed Consent to Medical Treatment, 11 Clev.-Mar. L. Rev. 249 (1962), or nominal damages for the invasion of hodily security where plaintiff could not show actual harm. Id.; see McCoid, supra at 417.

In states where the statutes of limitations in äctions for battery and for neghigent malpractice differ, it will be important to determine which period controls. Where the question has been considered, courts have been willing to circumvent short periods of limitation in order to avoid the har where a longer malpractice period of limitation exists. See Maercklein v. Smith, 129 Colo. 72, 76-78, 266 P.2d 1095, 1097-98 (1954); Hershey v. Peake, 115 Kan. 562, 233 P. 1113 (1924).

Battery might be viewed as a criminal act which would negate the insurer's liability since most malpractice policies lave clauses specifically disclaiming liability for criminal acts. Schroeder, Insurance Protection and Damage Awards in Medical Malpractice, 25 O파 St. L.J. 323, 330 (1965); see Levin, Consent to Medical Procedures, 1963 Ins. L.J. 711, n.7 \& 712 (1963); cf. Sheliee v. Aetna Cas. \& Sur. Co., 122 F. Supp. 1, 4 (W.D. La. 1954); Johnson, Medical Malpractice-Doctrines of Res Ipsa Loquitur and Informed Consent, 37 Coro. L. Rev. 182, 191 (1965). However some policies specifically itemize assault and battery as a contingency insured against. Committee on Medicolegal Problems, Professional Liability and the Physician, 183 J.A.M.A. 695, 701 (1963). Conditions in the policy will determine coverage, Glesby v. Hartford Accident \& Indem. Co., 6 Cal. App. 2d 89,44 P.2d 365 (1935), but where a narrow construction of the policy would prevent recovery, some courts have reasoned that, since a doctor would not operate without consent, failure to get that consent is a "mere oversight" and hence malpractice. Shehee v. Aetna Cas. \& Sur. Co., supra, at 6 . Not all courts will strain to effectuate insurance coverage.

19 Natanson v. Kline, 186 Kan. 393, 350 P.2d 1093, modified, 187 Kan. 186, 354 P.2d 670 
create new law in an area of judicial uncertainty, have simply adopted the "professional" standard of negligence as the measure of duty to disclose. Adoption of this standard has inadequately protected the patient's right of self-determination.

\section{A. The Professional Standard}

The professional standard of due care is based on the custom of a profession. ${ }^{20}$ The standard has been expressed in many different ways, ${ }^{21}$ but it commonly states first, that complance with custom is sufficient to avoid liability $^{22}$ and second, that plaintiff generally must establish his case through expert testimony. ${ }^{23}$ Although custom is usually no defense to a suit for negligence, ${ }^{24}$ the medical profession enjoys the privilege of adopting its own custom as a standard of due care. ${ }^{25}$ This is justified as being the only workable test ${ }^{26}$ in an area where the lay person is thought incapable of evaluating a doctor's conduct and where the courts want to allow doctors a great deal of discretion. ${ }^{27}$ Expert testimony is required because lay people presumably do not know what the custom is. ${ }^{28}$

(1960). The standards were: substantial disclosure, $186 \mathrm{Kan}$. at 406, 350 P.2d at 1103; full disclosure, $186 \mathrm{Kan}$. at 411,350 P.2d at 1107; reasonable disclosure, 187 Kan. at 189, 354 P.2d at 673; and no disclosure, id. Such a profusion of standards has created predictable confusion in the Kansas Bar. See Dale, Court Decision, 62 J. Kar. MEd. Soc'y 2 (1961). Mr. Dale, attorney for the Kansas Medical Society, wrote that Kansas physicians would incur liability if they made no disclosure, but Dale failed to warn of potential liability under the three other Kansas standards requiring a more complete explanation of risks. Three years later the Kansas court ended the confusion by settling on one standard, requiring that disclosure "which a reasonable medical practitioner would make under the same or similar circumstances." Williams v. Menehan, 191 Kan. 6, 8, 379 P.2d 292, 294 (1963).

20 W. Prosser, Handbook of the Law of Torts § 32, at 168 (3d ed. 1964); McCoid, The Care Required of Medical Practitioners, 12 VAND. L. REv. 549, 606 (1959) [hereinafter cited as McCoid, Medical Practitioners].

21 For a sample see McCoid, Medical Practitioners, supra note 20, at 558-59. Among those verbalizations are: "good medical practice;" "means and methods generally used by physicians ... of ordinary skill;" "skill and care commonly possessed and exercised by reputable physicians practicing in the same locality."

22 Lambert, Malpractice Liability Concepts Afecting All Professions, in Medrcar MaIPRACTICE-THE ATL SEMTTAR 7 (Harolds \& Block eds. 1966).

$23 \mathrm{McCoid}$, Medical Practitioners, supra note 20, at 560. For a list of cases requiring proof of negligence in medical malpractice by expert testimony see Morris, Medical Malpractice A Changing Picturel 23 Ins. Counser J. 23, 31 n.29 (1956).

24 Lambert, supra note 22 , at 7.

$25 \mathrm{Id}$. at 9; W. Prosser, HaNdBoox of the LaW of TORTS $\S 32$, at 168 (3d ed. 1964).

20 Lambert, supra note 22 , at 8.

27 McCoid, Medical Practitioners, supra note 20, at 607-08. The inequity of allowing a physician's discretion to determine which risks his patient will undergo will be considered in notes 79-83 infra and accompanying text.

28 E.g., Decho v. Shutkin, 144 Conn. 102, 106, 127 A.2̇d 618, 620 (1956); see Committè on Medicolegal Problems, Professional Liability and the Physician, 183 J.A.M.A. 695, 698 (1963): "The reason for this is that only a physician can tell when another physician has deviated from the required standard of care. A lay person, who does not know what a 
The majority of courts follow the professional standard in determining whether there was a duty to disclose a given risk. The largest group of courts within the majority holds that the duty to disclose will be determined by the custom and practice of physicians within the community. ${ }^{20}$ Other majority courts require a doctor to disclose what a reasonable doctor would disclose under the circumstances. ${ }^{30}$ Under a variant of these two views, the duty of disclosure is determined by "good medical practice." ${ }^{\prime 31}$ While verbalization of the standard varies, courts in the majority uniformly require expert testimony to establish a duty to disclose. ${ }^{32}$

\section{B. Deviations from the Professional Standard}

Courts have occasionally strayed from the language of the professional standard. It is impossible to say that these deviations from the majority standard represent a true minority standard because the rule announced in each instance was limited to the facts of the case, ${ }^{33}$ or has since been specifically overruled, ${ }^{34}$ or is no longer followed. ${ }^{35}$

The most puzzling standard in the area is found in Salgo v. Leland Stanford Jr. University Board of Trustees, ${ }^{36}$ decided prior to an ensuing wave of judicial interest in informed consent. This California case imposes hability on the physician "if he withholds any facts which are necessary to form the basis of an intelligent consent." ${ }^{\prime 37}$ In the face of apparent absolute liability for nondisclosure, the physician is allowed "a certain

physician is supposed to do in the first place, obviously cannot tell when he has not done it." But see notes 50-53 infra and accompanying text, suggesting that the modern jury can often know what a doctor should do fully as well as the doctor does.

29 E.g., DiFilippo v. Preston, 53 Del. 539, 173 A.2d 333 (1961); Roberts v. Young, 369 Mich. 133, 119 N.W.2d 627 (1963); Govin v. Hunter, 374 P.2d 421 (Wyo. 1962).

30 See, e.g., Ditlow v. Kaplan, 181 So.2d 226, 228 (Fla. App. 1965).

31 Shetter v. Rochelle, 2 Ariz. App. 358, 409 P.2d 74 (1965), modified, 2 Ariz. App. 607, 411 P.2d 45 (1966).

32 Difilippo v. Preston, 53 Del. 539, 549, 173 A.2d 333, 339 (1961); Ditlow v. Kaplan, 181 So.2d 226, 228 (Fla. App. 1965); Grosjean v. Spencer, 140 N.W.2d 139 (Iowa 1966); Haggerty v. McCarthy, 344 Mass. 136, 141, 181 N.E.2d 562, 566 (1962); Roberts v. Young, 369 Mich. 133, 119 N.W.2d 627 (1963); Aiken v. Clary, 396 S.W.2d 668 (Mo. 1965); Govin v. Hunter, 374 P.2d 421 (Wyo. 1962).

${ }^{83}$ See Mitchell v. Robinson, 334 S.W.2d 11 (Mo. 1960); Woods v. Brumlop, 71 N.M. 221, 377 P.2d 520 (1962).

34 See note 12 supra.

${ }^{85}$ Dunlap v. Marine, 242 Cal. App. 2d 162, 177, 51 Cal. Rptr. 158, 167 (1966), rejected plaintiff's contention that Salgo v. Leland Stanford Jr. Univ. Bd. of Trustees, 154 Cal. App. 2d 560, 317 P.2d 170 (1957), discussed infra notes 36-39 and accompanying text should control on the issue of infonned consent. Dunlap, supra, held that Tangora v. Matanky, 231 Cal. App. 2d 468, 42 Cal. Rptr. 348 (1964), bad decided that the determinative issue in an informed consent case in California was whether the pbysician had acted in conformity with recognized practices in the commumity.

36154 Cal. App. 2d 560, 317 P.2d 170 (1957).

87 Id. at 578,317 P.2d at 181. 
amount of discretion. ${ }^{338}$ Although it is rather difficult to determine what is a "certain amount of discretion," Salgo's language is often quoted but rarely analyzed. Two factors which are involved in Salgo's "discretion"the plaintiff's mental and emotional condition-are sometimes used by majority jurisdictions to justify limiting the duty to disclose..$^{39}$

Courts have not relied on the majority standard where they think the medical treatment involved was new and radical or where there was total nondisclosure of risks. ${ }^{40}$ Faced with such a case, courts have either waived the requirement of expert testimony ${ }^{41}$ or shown a greater willingness to impose liability. In cases of total nondisclosure where the pliysician controverts allegations of nondisclosure, courts occasionally treat the doctor's testimony as an admission of a duty to disclose, ${ }^{42}$ thus eliminating the need for expert testimony. The court may feel that common knowledge alone indicates the need for some disclosure. This feehing has led to cases requiring a "full and frank disclosure . . . of all pertinent facts." 33

While a plrysician is not expected to reveal all risks, ${ }^{44}$ the court's view of undisclosed, collateral hazards may influence it to make an exception to the requirement of expert testimony. Plaintiffs usually win in higl risk cases and usually lose where the courts think the risks left undisclosed were not very great. ${ }^{45}$

38 Id. One authority has suggested that this view is the one most sensitive to the needs of both doctor and patient. Interview with Dr. Harold Williams, coauthor of D. LourserL \& H. Williams, Triat of Medical Matpractice Cases (1966), in Berkeley, Nov. 21, 1966, on file with the California Law Review.

39 See Roberts v. Wood, 206 F. Supp. 579, 582 (S.D. Ala. 1962).

40 E.g., Mitchell v. Robinson, 334 S.W.2d 11 (Mo. 1960); Woods v. Brumlop, 71 N.M. 221, 377 P.2d 520 (1962).

41 Cases cited note 40 supra.

42 See Steele v. Woods, 327 S.W.2d 187 (Mo. 1959); Scott v. Wilson, 396 S.W.2d 532 (Tex. Civ. App. 1965). The breach of that duty is established when the trier of fact decides that the defendant did not make such a disclosure. But see Note, 34 So. CaL. L. REV. 217, 221-22 (1961), criticizing the court in Natanson v. Kline, 187 Kan. 186, 354 P.2d 670 (1960), for giving this effect to defendant's answer which had raised the defense of assumption of risk.

Many courts, e.g., Sheffield v. Runner, 163 Cal. App. 2d 48, 51, 328 P.2d 828, 830 (1958), have similarly used the defendant's admissions to establish the standard in other areas of medical negligence, thus relieving plaintiff of the requirement of expert testimony.

43 Woods v. Brumlop, 71 N.M. 221, 227, 377 P.2d 520, 524 (1962). This case involved injuries resulting from shock therapy and an allegation of total nondisclosure of risks. The court did not require expert testimony but limited the full disclosure requirement to the facts of the case.

44 See Stottlemire v. Cawood, 213 F. Supp. 897 (D.D.C.), new trial denied, 215 F. Supp. 266 (1963); Bell v. Umstattd, 401 S.W.2d 306 (Tex. Civ. App. 1966).

45 Plaintiffs have won in cases involving shock therapy: Mitchell v. Robinson, 334 S.W.2d 11 (Mo. 1960); Woods v. Brumlop, 71 N.M. 221, 377 P.2d 520 (1962); see Johnston v. Rodis, 251 F.2d 917 (D.C. Cir. 1958), holding that it was improper to grant summary judgment for the defendant doctor and granting a new trial. A plaintiff also won in a case 


\section{Criticism of the Majority Standard}

Continued reliance on the professional standard as the measure of duty of disclosure can be criticized both because there is no real community standard of disclosure and because there is difficulty in obtaining expert testimony.

\section{There is no Community Standard.}

In a malpractice case expert testimony establishes the community custom, and uncontradicted expert testimony binds the jury..$^{48}$ Establisling community custom through expert testimony is perfectly acceptable where such custom exists. However, because a physician supposedly considers his patient's emotional and mental as well as his physical condition in deciding to disclose, ${ }^{47}$ and because each patient is mentally and emotionally unique, there can be no single established custom concerning disclosure; if there is one, it is so general as to be of little value. ${ }^{48}$

An expert witness, not bound in his testimony by an established custonl, can testify in one of two fashions. He can say what he would have done under the circumstances, or he can say what he thinks a reasonable doctor would have done under the circumstances. In either case, the plyysician is constructing a personal standard and is not really stating the custom of a professional community. ${ }^{49}$

Custom is allowed to set the standard of care for the medical profession because a jury presumably does not know what doctors should do. ${ }^{50}$ It is submitted, however, that in the absence of established custom, a jury

involving radiation therapy, Natanson v. Kline, $186 \mathrm{Kan} .393,350$ P.2d 1093, modified, 187 Kan. 186, 354 P.2d 670 (1960). Courts consider these to be high risk, new and radical methods of treatment. However, a doetor need not disclose the risk of infection in major surgery, Roberts v. Young, 369 Mich. 133, 119 N.W.2d 627 (1963), nor the possible paralysis of vocal cords involved in a subtotal thyroidectomy, DiFilippo v. Preston, 53 Del. 539, 173 A.2d 333 (1961); Watson v. Clutts, 262 N.C. 153, 136 S.E.2d 617 (1964). Bult cf. Patrick v. Sedwick, 391 P.2d 453 (Alaska 1964), where plaintiff lost on her informed consent theory but recovered on an alternate theory of negligence in performing the subtotal thyroidectomy.

48 Danielson v. Roche, 109 Cal. App. 2d 832, 835, 241 P.2d 1028, 1030 (1952), interpreting Engelking v. Carlson, 13 Cal. 2d 216, 88 P.2d 695 (1939). The jury is allowed neither to substitute a standard of its own, Johnston v. Brother, 190 Cal. App. 2d 464, 467 n.1, at 469, 12 Cal. Rptr. 23, 26 (1961), nor, in most cases, to consider whether the professional standard is reasonable.

47 Roberts v. Wood, 206 F. Supp. 579 (S.D. Ala. 1962), Committee on Medicolegal Problems, supra note 28 , at 698 , says that the physician should consider the intelligence, personality and condition of the patient in making a disclosure. Physicians frequently abuse this rationale by offering it as a justification for nondisclosure. The plaintiff's mental and emotional state at the time of consultation is not readily susceptible of proof or disproof by either side.

48 Note, 75 HaRv. L. Rev. 1445, 1447 (1962).

$40 I d$.

50 Committee on Medicolegal Problems, supra note 28, at 698 . 
can set a standard just as well as an interested expert witness. ${ }^{51} \mathrm{~A}$ jury, unlike an expert witness, feels no reluctance to criticize a fellow physician. ${ }^{52}$ Specialized knowledge is not required to determine which risks are relevant in deciding whether or not to submit to an operation. ${ }^{63}$ Since neither the jury nor the court is motivated by professional self-interest, they are more likely than an interested expert witness to reach a reasonable conclusion about the duty to disclose.

\section{Diffculty in Obtaining Expert Testimony}

Courts recognize the near inpossibility of a plaintiff obtaining favorable expert testimony in a nualpractice action. ${ }^{54}$ The attitude of the medical profession toward malpractice actions las helped create this conspiracy of silence. "The physician must avoid destructive and unethical criticism of the work of other physicians." of twenty-one commandments appearing in the Journal of the American Medical Association, is designed to combat the "continuing existence of the unpleasant professional hability situation."

51 The Journal of the American Medical Association, which presumably expresses the feelings of many doctors, often prints such statements as these: "Professional liability litigation is regarded by many as a contagious disease of the social body, because the winning of a suit inevitably encourages the filing of others as patients become increasingly suit conscious. Each successful defense of an unjust suit on the other hand, serves as a discouragement to the filing of others." Committee on Medicolegal Problems, supra note 28, at 702. On the unjust nature of malpractice claims see Medicine and the Law, Medical-Legal Problems and Their Solutions, 165 J.A.M.A. 699, 700 (1957): "[T]he blunt truth is that the majority of all professional liability claims ... are without merit."

62 For the views of writers who discuss this reluctance, see D. LOUISEII \& H. WIIIIAMS, Truat of Medical Matpractice Cases $\pi$ 6.03, at 153 (1966); McCoid, A Reappraisal of Liability for Unauthorized Medical Treatment, 41 MINN. L. REv. 381, 432-34 (1957).

53 Note, 75 HARv. L. REv. 1445, 1447 (1962). One of the reasons often given for the requirement of expert testimony is that laymen cannot understand the techmical complexities of medical practice. E.g., Brown v. Keaveny, 326 F.2d 660, 661 (D.C. Cir. 1963).

54 Christie v. Callahan, 124 F.2d 825, 828 (D.C. Cir. 1941); Huffman v. Lindquist, 37 Cal. 2d 465, 484, 234 P.2d 34, 46 (1951) (dissent). In Huffman Justice Carter said, "Anyone familiar with cases of this character knows that the so-called ethical practitioner will not testify on behalf of a plaintiff regardless of the merits in his case." In Gist v. French, 136 Cal. App. 2d 247, 258, 288 P.2d 1003, 1010 (1955), the court held that it was not prejudicial error for the trial judge to remark to the jury that doctors were reluctant to testify about their fellow practitioner's negligence. The court noted that the remark was "merely an open recognition of the truth of the popular legend."

55 Committee on Medicolegal Problems, supra note 28, at 703.

${ }^{56} \mathrm{Id}$. at 702. This avoidance of criticism of another's work extends beyond appearance as a plaintiff's expert witness. Medicine and the Law, Analysis of Professional Liability Claims and Suits, 165 J.A.M.A. 608, 611-12 (1957), stated that the typical malpractice plaintiff commenced her action only after hearing her current physician criticize the treatment rendered by defendant. D. LouisecL \& H. WIHIIAMS, supra note 52, II 5.01-5.02, at 135-38, indicates that the physician-patient relationship is very emotional. When the relationship is broken, usually after some real or imagined social affront on the part of the physician, the patient will be very angry. If there has been a bad result involved, an 
Physicians have many reasons for being reluctant to testify against one another. Because medical science is mexact and unpredictable it is difficult to define "reasonable medical practice." may threaten to cancel the hability insurance of a doctor who plans to testify for plaintiff, ${ }^{58}$ or the company may choose to increase local premiums sharply after a successful malpractice suit. Feelings of professional camaraderie make a doctor reluctant to criticize another's work unless there is an obvious violation of good practice. ${ }^{59}$ A county medical society may subtly censure a physician who testifies for a plaintiff ${ }^{30}$ or may even cast him from the society. ${ }^{61}$ Finally, doctors distinguish bad practice from malpractice. ${ }^{62}$ They view bad practice as something they themselves would not do, but not as sufficient grounds for imposing liability.

This subconscious differentiation between two kinds of wrongs, bad practice and malpractice, confuses the area of informed consent where there is no clear standard ${ }^{63}$ to guide witnesses sympathetic to the defendant ${ }^{64}$ Requiring the plaintiff to present expert testimony that a standard does exist and was breached may well impose an insuperable burden. ${ }^{65}$

The requirement of expert testimony seems even more onerous when it is realized that physicians "flock to the defense" of a fellow physician who is charged with malpractice, ${ }^{66}$ and that their testimony, unless contradicted, binds the jury. ${ }^{67}$

ex-patient is very likely to sue at the drop of a hint of the defendant's possible negligence. Williams Interview, supra note 38.

57 Committee on Medicolegal Problems, supra note 28, at 695; McCoid, Reappraisal of Liability, supra note 52 , at 433 .

58 Huffman v. Lindquist, 37 Cal. 2d 465, 484, 234 P.2d 34, 46 (1951) (dissent); Belli, An Ancient Therapy Still Applied: The Silent Medical Treatment, 1 VIIL. L. REv. 250, 253-56 (1956).

50 Belli, sulpra note 58, at 255; McCoid, Reappraisal of Liability, sulpra note 52, at 433.

60 Belli, supra note 58, at 256. See Huffman v. Lindquist, 37 Cal. 2d 465, 484, 234 P.2d

34, 46 (1951) (dissent).

61 See Bernstein v. Medical Ass'n, 139 Cal. App. 2d 241, 293 P.2d 862 (1956).

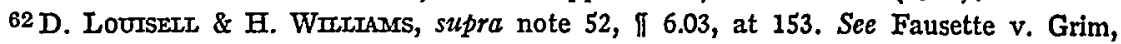
193 Mo. App. 585, 186 S.W. 1177 (1916).

63 See notes $47-49$ supra and accompanying text.

${ }^{04}$ See notes 51-52 supra and accompanying text.

65 The existence of informed consent actions cast in battery terms in the lope of evading the expert testimony requirement lends support to this view.

66 Huffman v. Lindquist, 37 Cal. 2d. 465, 484, 234 P.2d 34, 46 (1951) (dissent). Belli, supra note 58, at 254, suggests that defense witnesses often perjure themselves on the stand to bolster a case. Belli further charges that records are altered, reports are "lost," and outright perjury occurs at a higher rate in medical malpractice suits than in any other field of law. Dr. Harold Williams declares that at least $75 \%$ of defendant physicians in his malpractice cases perjure themselves on deposition as agamst $1-2 \%$ of plaintiff patients. Williams Interview, supra note 38 .

67 Cases cited note 46 supra. 
II

THE PROPOSED NEW STANDARD

It is submitted that the law's strong predisposition toward personal control over bodily invasions has been violated by the current judicial treatment of informed consent. That predisposition could be more effectively served if the following standard were adopted:

A physician is under an obligation (1) to make a full disclosure of all known material ${ }^{88}$ risks in a proposed operation or course of treatment except for those risks of which the patient is likely to $\mathrm{know}^{69}$ or (2) to prove the reasonableness of any lesser disclosure or the immateriality of the undisclosed risk. ${ }^{70}$

Current standards of disclosure do not protect Wendy Smith and others similarly situated. This Part proposes a new standard which, if applied, would protect Wendy. Part III then examines tlie background, effects and abuses of both the current and proposed standards.

68 The materiality of a risk is a function of the mcidence and severity of that risk. Risks which occur frequently but which are not very severe are material, as are risks which are very severe but which do not often occur. The ultimate question of materiality is whether knowledge of the risk before the patient gave his consent would have altered the patient's decision. The plaintiff in an informed consent action, with the benefit of hindsight, will always allege that such knowledge would have caused him to refuse consent.

Some risks may possess particular significance depending upon the individual. The risk of loss of the voice inherent in a subtotal thyroidectomy, notes 1-3 supra and accompanying text, would have particular significance to an amateur opera singer or a disc jockey. The patient may have expressed particular anxiety about certain forms of risks. This element of "particular significance" should be a factor in determining the materiality of a risk only where the doctor is aware of its importance to the patient.

${ }^{69}$ Some risks are common to all operations, and an adult with average intelligence will not be heard to say that he was not aware of them. See Roberts v. Young, 369 Mich. 133, $137-38,119$ N.W.2d 627, 629 (1963) (risk of infection during major surgery). If the risk is not a common one the doctor would have the burden of proof that it was reasonable to believe that the patient was alrcady aware of that risk.

70 This standard differs from the standard proposed by Dr. Williams. He feels that a physician should not be under a duty to volunteer information about risks. The physician should be able to rely on the assunption that most people know that there are some risks in any surgery, and that if they really want to know wbat those risks are, they will ask. Williams Interview, supra note 38.

Under Willians' view the doctor would outline the steps in an operation or course of treatment. The patient could ask about risks involved in any of the various steps, for example, use of an anesthetic. The doctor would be under a duty to give a truthful answer to that question but would be under no duty to volunteer inore than was asked. Naturally the depth of a patient's inquiries about risks would depend upon his knowledge of risks in a given procedure. This would mean that a patient who lacked sufficient knowledge to make an inquiry about risks would not be informed of those risks. Williams justifies this on the ground that it is precisely this sort of patient who would overreact to knowledge of the risks.

Reliance on the patient to initiate a discussion about risks has two advantages in Williams' opinion. First, it shows that the patient was really concerned about risks before the operation. This evidence of the patient's concern tends to prove that had the patient 


\section{A. Bases of the Proposed Standard}

"Every human being of adult years and sound mind has a right to determine what shall be done with his own body; and a surgeon who performs an operation without his patient's consent commits an assault, for which he is hable in damages."71 The right to determine what shall be done with one's own body is one of the fundamental premises of AngloAmerican law. ${ }^{72}$ Holmes, ${ }^{73}$ Cardozo,${ }^{74}$ and Frankfurter ${ }^{75}$ among others, ${ }^{70}$ have stressed the law's strong preference for an individual's control over invasions of his bodily integrity. The law's predisposition toward the patient's right can be explained, first, by analogy to the consent of a minor and, second, in terms of fundamental fairness.

\section{Consent of a Minor}

The rule that minors cannot consent to a surgical operation is based upon the supposition that a minor cannot appreciate the consequences of an operation. ${ }^{77}$ Similarly, when an adult is not told of possible serious

been told of the risks, he would not have consented. Second, it keeps patients from being told things that they do not want to know. Id.

71 Schloendorff v. Society of N. Y. Hosp., 211 N.Y. 125, 128, 105 N.E. 92, 93 (1914) (dictum) (Cardozo, J.). Defendant hospital had raised the defense of charitable inmunity against claims arising from the negligence of physicians or nurses. Cardozo, characterizing the physician's acts as trespass and not negligence, decided the case on the ground that the hospital was not liable for the acts of an independent contractor.

72 Natanson v. Kline, 186 Kan. 393, 406, 350 P.2d 1093, 1104 (1960), modified, 187 Kan. 186, 354 P.2d 670 (1960): "Anglo-American law starts with the premise of thorough-going self determination. It follows that each man is considered to be master of his own body, and he may, if he be of sound mind, expressly prohibit the performance of life-saving surgery, or other medical treatment." A doctor can believe that an operation is necessary, "but the law does not permit him to substitute his own judgment for that of the patient. ... ."Id. at 406-07, 350 P.2d at 1104.

73 Stack v. New York, N.H. \& H.R.R., 177 Mass. 155, 157, 58 N.E. 686, 687 (Holmes, J): "The common law was very slow to sanction any violation of or interference with the person of a free citizen."

74 Schloendorff v. Society of N. Y. Hosp., 211 N.Y. 125, 105 N.E. 92 (1914).

75 Sibbach v. Wilson \& Co., 312 U.S. 1, 17 (1941) (dissenting opinion): The "inviolability of a person" has such historic roots in Anglo-American law that it nuay not be curtailed "unless by clear and unquestionable authority."

70 Union Pac. Ry. v. Botsford, 141 U.S. 250, 251 (1891) ("No right is held more sacred, or is more carefully guarded, by the common law, than the right of every individual to the possession and control of his own person, free from all restraint or interference of others, unless by clear and unquestionable authority of law."); Salgo v. Leland Stanford Jr. Univ. Bd. of Trustees, 154 Cal. App. 2d 560, 578, 317.P.2d 170, 181 (1957); Bennan v. Parsonnet, 83 N.JL. 20, 25, 83 A. 948 , 950 (Sup. Ct. 1912).

77 E.g., Bonner v. Moran, 126 F.2d 121 (D.C. Cir. 1941); W. Prosser, Handbook or IHE LAW or TORTS $\$ 18$, at 103 (3d ed. 1964). Many authorities have criticized this blanket assumption of the incapacity of minors. H. Nathan, Medrcar Negcigence 176 (1957) argues that a child capable of appreciating fully the nature and consequences of a particular operation should be able to give legally effective consent. Consent of the parents would not 
consequences of proposed treatment, he is unable to appreciate them. Just as a minor cannot consent to an operation because he is too young to do so intelligently, so an uninformed adult cannot consent because he is too ignorant to do so intelligently. ${ }^{78}$

\section{Fundamental Fairness}

Where there is no problem of consent, and where harm results from an operation, the doctor need only compensate the patient for neghigence. Since the patient bears the entire risk of nonneghigent injury ${ }^{79}$ and is concerned with his own interests as no other person can be, it is only fair to allow him to choose between accepting or rejecting the hazards of a proposed treatment even if his choice is irrational. ${ }^{80}$

If a squeamish individual would rather not know about the potential hazards of treatment, he may delegate control to his physician through a conscious, knowing waiver. The physician presumably desires the best for his patient. ${ }^{81}$ But the doctor who proceeds under the doctor-knows-best theory without securing a deliberate waiver from his patient and without disclosing collateral hazards substitutes his judgment about the desirability of undergoing a risk for that of his patient. ${ }^{82}$ Such substitution is incon-

be necessary. Curran, Cogitations on the Law of Torts and the Child, in NACCA, TrarSCRIPT, FouRTEENTH ANNUAT Convention 320 (1960), suggests that the trend in the area is toward a factual test of the individual child's capacity to understand and urges that this is much more fair. W. ProssER, supra at $104 \&$ n.50, notes that minors approaching maturity have been held competent to consent to minor operations. Prosser argues that the same reasoning should apply to major operations but concedes that no court has yet done that. In Bonner v. Moran, supra, the trial court based its instruction to the jury on RESTATEMENT OF TORTS $\$ 59$ (1934), which states that a minor's consent is good if he can appreciate the nature, extent, and consequences of an invasion. The D.C. Circuit reversed, holding that the instruction was erroneous. The court noted in passing that the defendant had failed to make any explanation of the extent and nature of the operation to the 15-year old plamtiff.

78 While some risks, such as infection, are common knowledge, Roberts v. Young, 369 Mich. 133, 137-38, 119 N.W.2d 627, 629 (1963), risks peculiar to an operation are probably not known to the patient.

70 Courts have repeatedly held that, absent an express promise, a physician is not a warrantor of his treatment. W. Prosser, HANDBOOK of THE LAW OF TORTS § 32, at 165 (3d ed. 1964).

80 Smith, Antecedent Grounds of Liability in the Practice of Surgery, 14 RockY MT. L. REv. 233, 237 (1942) [hereinafter cited as Smith, Antecedent Grounds of Liability]. Smith argues that the patient can always be trusted to define his interest better than anyone else and that, while a patient may choose a foolish and even disastrous course, such a choice is his right. Smith would not consider death from a refusal of surgery to be suicide. Smith does not consider the converse situation where the patient's fear of his disease may lead him foolishly to accept surgery.

81 See Watson v. Clutts, 262 N.C. 153, 159, 136 S.E.2d 617, 621 (1964), holding that the doctor's primary duty is to do what is best for the patient, even if that means not disclosing a risk.

82 Smith, Therapeutic Privilege to Withhold Specific Diagnosis from Patient Sick with 
sistent with the law's respect for the patient's control over his own body. ${ }^{83}$ A society which believes each person should decide for himself which risks to assume is reluctant to let a doctor decide for his patient which risks to undertake while concealing those risks from the patient. This uneasiness is especially legitimate where the consequences of an operation may be worse than the results of having no operation at all. The right to control one's body can be protected only if one is allowed to choose between the continuance of a correctible defect or condition and the possible permanent loss of that bodily function. ${ }^{84}$

It is objectionably paternahstic for a physician to justify nondisclosure of risks on the ground that otherwise "both the patient and [physician] would back out." ${ }^{185}$ To tolerate such argument is to subordinate the patient's control of his body to his physician's absolute discretion.

\section{B. Significance of the Proposed Standard}

The proposed standard would shift part of the patient's burden of proof to the physician, requiring the plyysician to prove the reasonableness of his insufficient disclosure or the immateriality of the undisclosed risk. This shift in the burden of proof forces the physician to respect the law's strong predisposition toward self-determination. Proof of professional custom through expert testimony would be eliminated. Custom itself would only be a defense if the defendant proved that such custom was reasonable.

Such shifts are not without parallel in the field of malpractice. ${ }^{86}$ Several writers have suggested shifting the burden of proof in these and similar

Serious or Fatal Illness, 19 TeNs. L. Rev. 349, 350-51 (1946) [hereinafter cited as Smith, Therapeutic Privilege].

83 See Natanson v. Kline, 186 Kan. 393, 407, 350 P.2d 1093, 1104 (1960), modified, 187 Kan. 186, 354 P.2d 670 (1960); Bennan v. Parsonnet, 83 N.J.L. 20, 25, 83 A. 948, 950 (Sup. Ct. 1912). Smith, Therapeutic Privilege, supra note 82, at 350.

${ }^{84}$ Scott v. Wilson, 396 S.W.2d 532 (Tex. Civ. App. 1965), affd, 412 S.W.2d 299 (Tex. 1967). Plaintiff suffered permanent impairment of her hearing, correctible with a bearing aid, which plaintiff used. The physician induced plaintiff to consent to a stapes mobilization. The doctor admittedly knew that the operation could result in a permanent and total loss of hearing, death, or meningitis. Yet he did not tell his patient of these hazards. Plaintiff suffered a total and permanent loss of hearing. The court found the patient's uninformed consent to be ineffective and reversed and remanded a directed verdict for the defendant.

85 Yeates v. Harms, 193 Kan. 320, 327, 393 P.2d 982, 987 (1964). The opinion affirmed a jury verdict for defendant where the injury complained of-loss of an eye due to infection following cataract surgery-was from a risk not disclosed. The defendant testified that such results occurred in $11 / 2 \%$ of the cases he treated.

$86 \mathrm{D}$. Lounsell \& H. WILLIAMSS, supra note 52 , ch. 15 , at $461-84$, discusses the use of res ipsa loquitur as a device for shifting the burden of proof. They submit that "a rational legal order presupposes some suitable device to compel the professional man to disclose the facts needed by his patient or chient to comprehend an occurrence or transaction arising in the professional relationship." Id. at 464. While use of res ipsa loquitur is not the ideal 
cases $^{87}$ to breach the protective wall of expert testimony. ${ }^{88}$ Shifting the burden to the physician is to place it on the party most capable of bearing it. ${ }^{89}$

\section{How Would the Litigants Meet Their Burdens}

A patient suing under the theory of informed consent would file a complaint alleging: First, that his physician failed to inform him adequately of a particular risk in treatment before securing consent; second, that he did not know about the risk; third, that if he had known he would not have consented; and fourth, that the adverse consequences did in fact occur.

Since expert testimony is not required to prove these allegations, a patient dissatisfied with the results of treatment might be strongly inclined to sue. ${ }^{90}$ To discourage suits by such persons, courts should allow extensive use of physical examinations under Federal Rule of Civil Procedure 35 or its equivalent. ${ }^{91}$ Where a Federal Rule 35 examination reveals that the patient's condition has not been worsened by the treatment, careful attention should be given to the possibility of summary judgment for defendant.

At trial the plaintiff would offer proof of his allegations. Whether there was a failure to inform and whether the patient would have refused to consent had he known the risks are questions of fact which depend upon the jury's assessment of both the plamtiff's and physician's credibility. ${ }^{92}$

means to force doctors to communicate fully with their patients according to their patients' needs, it is the most appropriate doctrine available. Id. at 479. The courts have recognized that the need for protection of a patient may be such that a doctor will be required to explain the reasons for an imjury. E.g., Cho v. Kempler, 177 Cal. App. 2d 342, 347, 2 Cal. Rptr. 167, 170 (1960).

87 Johnson, Medical Malpractice-Doctrines of Res Ipsa Loquitur and Informed Consent, 37 Coro. L. REv. 182, 189 (1965); McCoid, Reappraisal of Liability, supra note 52, at 433-34. Johnson, however, would allow the community standard as a defense to an action without even questioning whether the community standard was reasonable.

88 Brown v. Keaveny, 326 F.2d 660, 663 (D.C. Cir. 1963) (dissenting opinion of Wright J.).

89 See text accompanying note 66 supra.

$90 \mathrm{~A}$ dissatisfied patient is one who received either temporary or no benefit from the operation. Although the patient is disappomted, he is no worse off than he was before the operation.

91 E.g., Car. Code Crv. Pro. \$ 2032 (West Supp. 1966).

92 Note, 75 HARv. L. REv. 1445, 1449 (1962). Dr. Willians urges that this credibility contest is one of the weaknesses of the imformed consent action. Interview, supra note 38 . The lawyer unconsciously shapes and molds the client's story. After an imterview the client, whether plaintiff patient or defendant doctor, will beheve that he said things which in truth he did not say, or was not told things whicl in truth he was told. There is no chicanery involved in this process but merely the natural reaction of a human under stress trying to reconstruct events which happened some time ago and which he now remembers hazily, at best. 
After the plaintiff's initial showing the doctor's first defense is to rebut plaintiff's proof. He could show that the risk which caused plaintiff's injury was satisfactorily disclosed, ${ }^{93}$ or that plaintiff had suffered no injury. The doctor could also show reasonable belief that the patient was already aware of the risk during consultation-an easy task where the undisclosed risk is common to all surgical treatment but of increasing difficulty where the risk is unusual. ${ }^{94}$

The physician can use expert testimony to establish his affirmative defenses. ${ }^{95}$ When such testimony is offered, however, plaintiff has the opportunity to cross-examine the experts and to use the defendant as an adverse witness. ${ }^{98}$ Under certain conditions, medical texts can be used to

93 If the plaintiff had signed a consent form the defendant would enter that form as evidence that disclosure was made. Dr. Williams stated that some writing corroborating defendant's allegations that disclosure was made exists in many informed consent actions. The fact that such records exist in so many cases leads Williams to conclude that plaintiff's attorneys are abusing the current theory by inserting unfounded informed consent claims into a complaint as an afterthought. Interview, supre note 38. Consider, however, LAw Dep's AmirRican Medicat Assoctation, Medicolegat Forars with Legai Analysis \& 16, at 31-32 (1961), which declares that many hospitals and doctors do not secure a written consent or, at best, use an inadequate "blanket" or general consent form to "such treatment . . . as found necessary . . . which is advisable." Understandably, courts have tended to limit the scope of such consents, Valdez v. Percy, 35 Cal. App. 2d 485, 96 P.2d 142 (1939), or give them no effect, Rogers v. Lumbermen's Mut. Cas. Co., 119 So.2d 649 (La. 1960).

While no particular form is required for a written consent, LAW DEP'T AMERICAN MEDICAL Association, supra, at 30, it should state clearly the nature and extent of the operation authorized and that the person signing it has legal capacity to consent. Id.; Levin, Consent to Medical Procedures, 1963 Iss. L.J. 711, 715. If possible, the consent form should be signed in the presence of a witness to facilitate proof. LAW DEp'T AxIERICAN MEDicat Assgctatron, supra, at 31; Morris, Malpractice: Medical-The Important Events of the Last Two Years, 30 INs. Counser J. 44, 56 (1963). The form should contain a clause stating that the risks have been explained, but if material risks were not disclosed the patient may be able to repudiate the consent form. Kloss, Consent to Medical Treatment, 5 MED. Scr. \& I. 89, 97-99 (1965). Inclusion of at least some of the possible consequences on the face of the form will aid in establishing that disclosure was actually made. Levin, supra, at 715. Contra, Oppenheim, Informed Consent to Medical Treatment, 11 Crev.-MLAR. L. REv. 249, 261 (1962). Oppenheim baldly declares that the whole trend toward informed consent is "ridiculous" and that an average patient could not understand a consent form which bore on its face the possible consequences of an operation.

While the doctor hopes that the specific language in the consent form will protect him from liability, he also wants to have a consent couched in the broadest terms possible to cover any contingencies. Levin, supra, at 715; Oppenheim, supra, at 264.

04 See Kloss, supre note 93, at 98.

95 The affirmative defenses are discussed at notes 99-103 infre and accompanying text.

98 CAL. EvID. CoDE $\$ 776$ (West 1966). For examples of the effective uses of such methods to secure damaging admissions, see Seneris v. Haas, 45 Cal. 2d 811, 291 P.2d 915 (1955); Lashley v. Koerber, 26 Cal. 2d 83, 156 P.2d 441 (1945); Lawless v. Calaway, 24 Cal. 2d 81, 147 P.2d 604 (1944); Madis v. Stellwagen, 38 Wash. 2d 1, 227 P.2d 445 (1951). The party of record or anyone identified with the party can be called as an adverse witness. While the party.calling the:witness is not bound by any adverse testimony elicited, Stein v. Superior Court, 174 Cal. App. 2d 21, 344 P.2d 406 (1959), the testimony is given its proper weight 
impeach expert witnesses. ${ }^{97}$ Requiring defendant to offer expert testimony as a defense makes expert witnesses available for cross-examination by the plaintiff, breaches the conspiracy of silence, and increases the knowledge available to the trier of fact..$^{98}$

The physician's first affirmative defense is the immateriahty of the risk. Plaintiff has the burden of going forward with evidence that he would not have consented had he known of the risk, while the defendant must prove that plaintiff would have consented had he known the risk. The doctor can accomplish this by showing, through expert testimony, that the risk was so minor or infrequent that knowledge of the risk was not essential to intelligent consent, ${ }^{99}$ or was so difficult to explain that it would place an unreasonable burden upon him to inform every patient of the risk. ${ }^{100}$

As a second affirmative defense, the doctor could prove that he was not and should not have been aware of the risk. Inexplicable and unpredictable results sometimes occur in the practice of medicine. ${ }^{101}$ Liabihty under the theory of informed consent is based upon failure to disclose known hazards; if the risks are unknown there should be no liability for failure to disclose, unless the physician's lack of knowledge of the risk was itself negligent.

subject to rebuttal of the testimony or impeachment of the witness. Leonard v. Commumity Hosp., 47 Cal. 2d 509, 305 P.2d 36 (1956). Under ch. 55, § 1, [1917] Cal. Stats. 58, predecessor of CAL. EvD. CODE $\$ 776$ (West 1966), defendant physicians were frequently examined as to the comniunity standard and whether their conduct conformed to it. McCurdy v. Hatfield, 30 Cal. 2d 492, 183 P.2d 269 (1947); Lawless v. Calaway, supra; Libby v. Conway, 192 Cal. App. 2d 865, 13 Cal. Rptr. 830 (1961).

${ }^{97} \mathrm{D}$. LoUTSEIL \& $\mathrm{H}$. WILIIAMS, supra note $52, \pi 11.19$, at 324 , gives a very complete discussion of the different rules which govern use of a medical treatise to impeach an expert witness. CAL. Evm. CODE $\S 721$ (West 1966) allows use of a medical treatise to impeach an expert witness only if the expert relied on that treatise in forming his opinion.

88 The extent of these effects will, in large part, depend upon the skill of the plaintiff's advocate, but expert witnesses, which plaintiff probably could not get into court, notes 54-67 supra and accompanying text, will at least be there. Their testimony will be a valuable aid to the trier of fact in making a correct decision. See Note, 52 IowA L. REv. 786, 789 (1967).

99 See Note, 75 Harv. L. Rev. 1445, 1448 (1962).

100 See Stottlemire v. Cawood, 213 F. Supp. 897 (D.D.C. 1963) (no liability), which involved an injection of the antibiotic chloromycetin to treat a minor ear infection. Expert testimony at trial indicated that there was one chance in 800,000 of aplastic anemia resulting from an injection of chloromycetin. Karchmer, Informed Consent: A Plaintiff's Medical Malpractice "Wonder Drug" 31 Mo. L. REv. 29, 41 (1966), argues that there is a societal interest in having a doctor see as many patients as possible. The Karchmer view would allow a doctor to take less time in telling a patient risks in order to treat more patients. Whether the amount of time saved, if any, would actually be used to see more patients is a matter of conjecture.

101 Cominittee on Medicolegal Problems, Professional Liability and the Physician, 183 J.A.M.A. 695 (1963). "Medicine is an art and at best an inexact science," and the desired results are not always achieved. Levin, Consent to Medical Procedures, 1963 INs. L.J. 711. However, the physician might be liable under a res ipsa loquitur theory. 
As a final defense the physician could prove that his patient's mental and emotional condition was such that it would have been therapeutically unwise to inform him of the risk. Courts which have allowed such a defense have reasoned that a disclosure which upset or unduly alarmed the patient increases the risks of the operation. ${ }^{102}$ This defense tacitly admits that the doctor was aware of the risk and that disclosure was essential to an informed consent. Although in some cases disclosure should not be made for the benefit of the patient, this defense should only be allowed if the physician has demonstrated his good faith by adequately disclosing the risks to a responsible relative. ${ }^{103}$ This defense can be too easily abused if no disclosure has been made to anyone.

III

\section{THE EFFECT ON MEDICAL PRACTICE}

It is submitted that current legal standards for disclosure are wrong and that increased disclosure of risks would better meet the needs of the patient and society. Whether adoption of the proposed legal standard would so influence the practice of medicine ${ }^{104}$ as to meet those needs depends upon two factors. First, do doctors have sufficient communica-

102 Lester v. Aetna Cas. \& Sur. Co., 240 F.2d 676, 679 (5th Cir. 1957); Roberts v. Wood, 206 F. Supp. 579, 582 (S.D. Ala. 1962). Karchmer, supra note 100, at 29, suggested that a disclosure of risks which made the patient a worse operative risk might be viewed as actionable malpractice. Whether a court would actually find the causing of such undue alarm to be actionable malpractice is in some doubt. Karchmer cites Ferrara v. Galluchio, 5 N.Y.2d 16, 152 N.E. 2d 249, 176 N.Y.S.2d 996 (1958), for the proposition that a disclosure whicl unduly alarmed the patient would constitute malpractice, but the citation is erroneous. In Ferrara the defendants made no disclosure. The patient's cancerphobia and mental anguisl was caused, not by disclosure, but rather by reasonable statements made by a second doctor about injuries inflicted during the original treatment. Liability was imposed through a causation analysis relating back to negligence in the original treatment.

Kraus v. Spielberg, 37 Misc. 2d 519, 236 N.Y.S.2d 143 (Sup. Ct. 1962), involved a woman suffering from tuberculosis phobia. In order to get his patient to submit to chemotherapy for stomach pains defendant physician falsely told her that tuberculosis germs were in her intestine. A directed verdict for defendant was affirmed on the grounds that "The statement . . . clearly was a requisite medical techmique to imduce plaintiff . . . to undergo the treatunent." Id. at 520, 236 N.Y.S.2d at 144-45. The Kraus court did not want doctors to be secretive and withhold information out of fear their frightened patients might turn on them. Id. at 521, 236 N.Y.S.2d at 146.

103 See Lester v. Aetna Cas. \& Sur. Co., 240 F.2d 676, 679 (5th Cir. 1957). Lester held that an adequate disclosure of the risks in shock therapy to the wife of the patient was sufficient. The wife and the physician had agreed that it would be best not to frighten the patient by disclosure of the risks. But see note 47 supra.

104 See Louisell, Lawyers, Doctors and Medical Malpractice: A Legal Viewpoint, in Medical Malpractice 59, 62 (Shapiro, Steingold \& Needham eds. 1965): "[I]n the real world self interest is still one of the great motivating factors of buman conduct. There are good reasons to beheve that the adoption of many safety rules in the practice of medicine . . . was hastened, significantly, by the pressure inherent in the possibility of hability for malpractice." 
tive ability to perform successfully under the suggested rule? Second, how would doctors' efforts to comply with the new standard affect medical methods and techniques?

\section{A. Doctors Can Communicate Successfully}

Unless physicians are able to communicate the nature of an operation's collateral hazards without causing the patient to lose confidence, the new standard will not reahize its maximum value.

\section{Ability to Make Intelligible Disclosures}

Some authorities have suggested that doctors may lack the ability to make adequate disclosure because certain risks are too technical for patients to understand. ${ }^{105}$ But others maintain that, in the normal case, candid disclosure of potential hazards can be made even if their causes cannot be effectively explained. ${ }^{108}$

Assuming the doctor is able to provide a complete nontechnical explanation, ${ }^{107}$ some authorities nevertheless argue that the average patient could not intelligently compare the risks of alternative methods of treatment and the risks of accepting or rejecting treatment. Some authorities insist that the average patient lacks the capacity to make an intelligent choice. ${ }^{108}$ However, such capacity is not required by the informed consent theory. The theory of informed consent vindicates the right to decline a risk; it does not insure that the decision to decline is wise. ${ }^{109}$

Fear and alarm generated by knowledge of the risks will influence a patient's decision to accept or reject those risks. ${ }^{110}$ Authorities agree that doctors must utilize great tact in disclosing risks; they disagree, how-

105 Karchmer, supra note 100, at 41 . See Roberts v. Wood, 206 F. Supp. 579, 583 (S.D. Ala. 1962). Karchmer suggests that years of experience and education are necessary to understand the risks involved in a given procedure. But see Note, 75 HARv. L. REv. 1445, 1448 (1962).

${ }^{108}$ Wasmuth, panelist in Guide to getting a patient's consent, MED. ECON. Nov. 28, 1966, at 79,82 , suggests that a doctor's legal duty is to forewarn the patient of the risks and dangers in the operation. Wasmuth says that it would be impossible to impart enough medical knowledge to inform the patient but that it is at least possible to forewarn him.

${ }_{107}$ Corn v. French, 71 Nev. 280, 282, 289 P.2d 173, 175 (1955), shows the need for a nontechmical explanation and consent form. Plaintiff signed a consent form for a mastectoiny (removal of the breast). The jury was allowed to decide whether the consent form was adequate. Plaintiff alleged that she did not know the meaning of the word "mastectomy," that she had told the doctor not to remove her breast, and that he had replied "I have no intentions of removing your breast. I wouldn't think of doing so without first making a test.'"

108 McCoid, Reappraisal of Liability supra note 52, at 431; Williams Interview, supra note 38.

109 Note, 75 HARv. L. Rev. 1445, 1448 (1962).

110 See Note, 1962 WASH. U.L.Q. 402, 416 \& n.72. 
ever, on whether doctors have enough tact to make sufficient disclosure without frightening patients away. ${ }^{111}$

The doctor who lacks necessary tact will often face a difficult choice. $\mathrm{He}$ can disclose the risks, thus frightening the patient away from a potentially beneficial treatnient. Alternatively, he can do what he thinks is best for the patient without disclosing the risk, in which case he is then hable for resulting injury. This potential liability can be limited if the physician consults with a responsible relative before deciding not to disclose. While the law does not permit him to substitute his judgment for that of his patient, ${ }^{112}$ the trier of fact would very likely find that nondisclosure under such circumstances was reasonable. ${ }^{118}$

\section{Confidence and the Doctor-Patient Relationship}

Because an essential element of successful medical treatment is the patient's confidence in his physician, ${ }^{114}$ the proposed standard poses certain problems. It has been suggested that a doctor, attempting to gain legal protection under such a standard, might dwell on risks to an excessive degree ${ }^{115}$ or inform patients of risks which they need not know to give intelligent consent. ${ }^{116}$ Unnecessary emphasis on risks would cause the patient to lose confidence in the physician and the physician to lose confidence in himself. ${ }^{117}$

These views have been challenged by an authority who doubts that telling a patient of risks involved in a particular treatment would cause him to lose confidence in his physician. ${ }^{118}$ The new standard requires

111 The defendant in Yeates v. Harms, 193 Kan. 320, 327, 393 P.2d 982, 987 (1962), said that he did not disclose all of the risks because if he did, both doctor and patient would back out. Dr. Williams suggests that doctors, as a class, could not perform successfully under any standard which required the volunteering of risks. Interview, supra note 38 . This attitude may stem from Williams' view that the most frequently occurring hazard im medicine is the possibility of a "goof" by the physician. The "goof" might be anything from simple minor error to actionable negligence, but prior admission of human fallibility is difficult for any individual. But see Oppenheim, supra note 93, at 264, arguing that doctors could tell their patients of risks in such a way as to impress them with the doctor's medical skill, judgment and ability to foresee risks.

112 See note 83 supra and accompanying text.

113 See note 103 supra and accompanying text.

114 D. Loutserx \& H. Writcaxs, supra note 52, I 5.03, at 138; Oppenheim, supra note 97, at 250. See Smith, Antecedent Grounds of Liability, supra note 80, at 237.

115 Williams Interview, supra note 38. See Regan, Panelist in Guide to getting a patients consent, MED. ECON., Nov. 28, 1966, at 79-80: "[A] doctor can go too far when explaining risks .... In their attempts to protect themselves legally, they were brutally cruel, describing surgical procedures in all their gory details . . . Well, the law makes no such demand." Regan noted that excessive frankness was just one extreme of disclosure practices. The other extreme is the assumption that the patient won't understand it anyway, so no disclosure is made.

116 Regan, supra note 115, at 80; Note, 1962 WASH. U.L.Q. 402, 416.

117 Williams Interview, supra note 38.

118 Oppenheim, supra note 93, at 264. 
disclosure of material risks only. The argument that preoperative disclosure of risks may cause loss of confidence ignores the effect upon that confidence of a postoperative discovery that an undisclosed risk has occurred. ${ }^{119}$

Some patients may not want to know the risks ${ }^{120}$ and would prefer to entrust themselves to the doctor's best judgment. ${ }^{121}$ While such patients do exist, it cannot be assumed that all patients feel that way. Therefore a doctor should proceed on the assumption that a patient wishes to know the risks unless, in response to an offer of disclosure, he declines and delegates his decision to the doctor.

\section{B. How Doctors Would Protect Themselves}

A new theory of hability, even if not automatically increasing the number of recoveries, at least offers an alternative ground of recovery. The American Medical Association, ${ }^{122}$ writers, ${ }^{123}$ and the courts ${ }^{124}$ have all expressed concern over the increasing number of malpractice actions. They depict the surgeon as operating in a world in which he is faced by an ever growing and increasingly skillful malpractice bar, representing litigation-conscious patients who expect medical miracles. ${ }^{125}$

Several writers liave argued that the increase in malpractice actions is undesirable. The threat of liability, it is urged, causes the doctor to make judgments to protect himself rather than to care for lis patient. ${ }^{126}$ This discourages doctors from assuming control of cases with poor prognoses and from using relatively new and successful, but possibly dangerous, techniques. ${ }^{127}$

The other view is that malpractice recoveries act as a valuable discipline to the medical profession, ${ }^{128}$ greatly improving the standard of

110 This follows from the presumption that a plaintiff in a malpractice suit has no confidence whatsoever in the defendant physician.

120 Williams Interview, supra note 38.

121 See Kennedy v. Parrott, 243 N.C. 355, 362-63, 90 S.E.2d 754, 759-60 (1956); McCoid, Reappraisal of Liability, supra note 52, at 431.

122 Committee on Medicolegal Problems, Professional Liability and the Physician, 183 J.A.M.A 695 (1963). The Committee states that malpractice claims increased one hundredfold between 1930 and 1950. One out of every four urban physicians will face a malpractice action during his career.

${ }^{123}$ D. Loursete \& H. Wurtiams, supra note 52, If 1.01, at 1-2; McCoid, The Care Required of Medical Practitioners, 12 VAND. L. Rev. 549, 609 (1959).

124 E.g., Agnew v. Parks, 172 Cal. App. 2d 756, 763, 343 P.2d 118, 122 (1959).

125 Committee on Medicolegal Problems, supra note 122, at 695.

128 Medicine and the Law, Medical-Legal Problems and Their Solutions, 165 J.A.M.A. 699, 700 (1957). See Levin, supra note 101, at 720; MeCleary, Torts in Missouri, 27 Mo. L. REv. 81, 88 (1962).

127 Medicine and the Law, supra note 126, at 700; Levin, supra note 101, at 720.

128 "No malpractice suit, whatever it may cost the physician, ever hurt the medical profession. Rather, it is like an invaluable discipline." Capecelatro, N.Y.L.J., Mar. 11, 1959, at 4 , cited in D. LouISExL \& H. WrItTAMS, supra note 52, If 1.02, at 4 n.10. 
practice. ${ }^{129}$ Both the "fear-of-liability" view and the "valuable discipline" view would cause doctors to make greater disclosures to their patients. One cause may be preferred over the other, but the end is recognized as good medical practice. ${ }^{130}$

Even if informed consent liability makes a physician act only to protect himself, adoption of the proposed standard would be desirable from the doctor's point of view. Several writers liave suggested that the number of malpractice claims might actually decrease if physicians were to tell their patients of the risks beforehand. ${ }^{131}$ The patient who is prepared for a bad result is less likely to sue out of slock and anger over the occurence of that result.

\section{CONCLUSION}

It has been shown that there is a generally recognized right to be told of the dangers inherent in proposed medical treatment. The right is consistent with the nature of the doctor-patient relationship and with fundamental fairness.

The current majority standard does not protect that right. In its reliance on nonexistent custom as the standard of disclosure and through its requirement of expert testimony it has ignored the needs of the patient in favor of the presumed needs of the physician. The requirement of expert testimony has too often made it impossible for a patient to vindicate lis rights.

Current standards are confused and subject to abuse. Adoption of the proposed standard requiring full disclosure of material risks would eliminate mucl confusion as to the basis and nature of informed consent. Under that standard, both patient and doctor would gain a clearer understanding of their respective rights and obligations.

\section{Michael Justin Myers}

129 Louisell, supra note 104. D. LOUISEIr \& H. WILIIAMrs, supra note 52, II 14.04, at 427 n.23, says that since the decision in Ybarra v. Spangard, 25 Cal. 2d 486, 154 P.2d 687 (1944), there has been improved shoulder padding on surgical tables. Ybarra involved a patient's shoulder ijury which was first discovered immediately after an operation.

130 "Good medicine-that's what you get when a patient knows what he's consenting to .... because a good doctor will inform his patient of the risks, all doctors are expected to." McCoid, panelist in Guide to getting a patient's consent, MED. EcoN., Nov. 28, 1966, at 79,87 .

131 Oppenheim, supra note 93 at 264; Note, 75 Harv. L. Rev. 1445, 1449 (1962); Note,

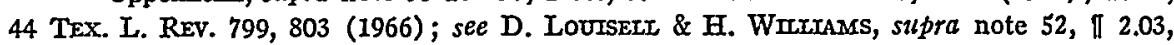
at 17 ; id. If 5.01 , at 136 ; id. \ 5.06 , at $142-43$. The authors empbasize the importance of explanation before any operation and after any disappointing result and the role such explanation serves in forestalling suits. Patients who do not understand become angry, and it is the angry patient who sues. 